\title{
BRIDGING THE GAP BETWEEN PRE-CENSUS AND CENSUS ERA HISTORICAL DATA: DEVISING A GEO-SAMPLING MODEL TO ANALYSE AGRICULTURAL PRODUCTION IN THE LONG RUN FOR SOUTHEAST EUROPE, I840-I897
}

\section{ERDEM KABADAYI, PIET GERRITS AND GRIGOR BOYKOV}

\begin{abstract}
This research introduces a novel geo-spatial sampling model to overcome a major difficulty in historical economic geography of Bulgarian lands during a crucial period: immediately before and after the de facto independence of the territory from the Ottoman Empire in the second half of the nineteenth century. At its core it seeks to investigate the research question how the Bulgarian independence affected agricultural production in two regions (centered around the cities of Plovdiv and Ruse) of today's Bulgaria, for which there are conflicting yet empirically unsubstantiated claims concerning the economic impact of the political independence. Using our be-spoke geo-sampling strategy we believe, we have sampled regionally representative commensurable agricultural data from the 1840s Ottoman archival documentation, in accord with agricultural censuses conducted by the nascent nation state of Bulgaria in the 1890s.
\end{abstract}

Keywords: Pre-census data, geo-sampling, spatial data calibration, agricultural suitability, connectivity, Ottoman Empire, Bulgaria

\section{INTRODUCTION}

The point of departure for this study has been an ever-present and fundamental research question for scholars of Bulgarian and Ottoman economic history: How did political independence and nation state building affect economic 
development in Bulgarian lands? There are conflicting claims on the economic impact of political independence for Bulgaria. In 1878 at the Congress of Berlin, Bulgaria gained political autonomy and was established as a de facto independent principality albeit nominally under Ottoman sovereignty. The Bulgarian principality included the Ruse region as an important centre for agricultural production and the city of Ruse as an inland export trade harbour on the Danube. In 1885 the province of Eastern Rumelia (approximately Southern Bulgaria) also joined the Bulgarian principality thus increasing its territorial cover similar to today's Bulgaria and became independent of Ottoman rule. Eastern Rumelia also compromised the Plovdiv region; another economic stronghold of Bulgarian lands with the city of Plovdiv and its industrial centre as its heart. During the communist regime (1946-1990), Bulgarian nationalist historiography made broad claims of Ottoman political rule being an element in stunting the economic development in Bulgarian lands via centrally organized surplus extractive institutions for centuries. ${ }^{1}$ This historiographical school of thought, along with communist rule, fell and have since been substantially revised in the 1990s. Scholars, such as Palairet, even argued that independence resulted in an economic decline in Bulgarian lands due to a sudden loss of export markets in the Ottoman Empire. ${ }^{2}$ A relatively recent study on Bulgarian agriculture focusing on the period between the declaration of the autonomous principality and the Balkan Wars (1878-1912) reviews these conflicting claims and clearly states that we have a data availability problem to reach conclusions about the impact of political independence on the economic performance in Bulgarian lands. ${ }^{3}$ The most recent and an exhaustive study also addresses the problems of measuring productivity and economic development due to difficulties of data interpretation. ${ }^{4}$ Since the economy of Bulgarian lands before and after the independence were overwhelmingly agrarian, we are convinced that focusing on agricultural production leads us to calibrate a new and initial research question: How did the Bulgarian independence affect agricultural production in two regions (centred around the cities of Plovdiv and Ruse) of today's Bulgaria? This research question is not only pragmatic but feasible in the scope of arriving at data proven conclusions. Answering this question is not free of challenges: commensurable datasets on agricultural production before and after the Bulgarian independence need to be created to provide a sufficient and meaningful answer. All the above cited works on Bulgarian economic history suffer from one shared yet major limitation: they do not systematically utilize mid-nineteenth century pre-census Ottoman archival documentation on agricultural production. These documents are available at the Ottoman state archives in Istanbul. However, they encompass micro level, household based, individual, handwritten information all of which has never been tabularised or aggregated. Hence, without employing a well-designed geo-sampling strategy, these data cannot be harvested and curated for a 
large-scale regional examination. With this study we are introducing a novel geospatial model to overcome this major difficulty for using mid-nineteenth century Ottoman micro level data for historical economic geography of Bulgarian lands.

Nevertheless, to our understanding our sampling model exhibits potential use for economic history writing also for the territories of other successor states of the Ottoman Empire and beyond. Generally, published census data, be it contemporary or historical, are territory-based and available in aggregated levels for administrative units with varying levels of spatial resolution. On the other hand, pre-census micro level individual economic data are normally point-based. In geo-spatial terms, we can attribute census data to polygons and pre-census individual data to points. As a result, we have developed a method to curate a commensurable panel dataset for agricultural production for regions and to bridge the pre-census Ottoman era in the 1840s and the census era for Southeast Europe and Turkey beginning in the 1880s, when successor states of the Ottoman Empire began conducting national, agricultural, and industrial censuses. Our model is an outcome of an interdisciplinary joint effort among historians and geospatial researchers retrieving, curating, and coding data from archival documents, historical censuses; and mapping and analysing these datasets for jointly posed analytical research questions.

\section{SOURCES}

In 1839, the Ottoman administration sought to abolish a well-entrenched tax farming practice. This reform attempt led to a nearly empire-wide survey of income yielding assets (temettuat registers) in the 1840s. The first wave of this survey was not successful, however, a second survey undertaken in 1844/1845 created a surplus of micro level economic data registered per household for the Ottoman economy. Consequently, this data revealed the Ottoman economy's heavy reliance on agriculture paired with an extremely low level rate of urbanization in relation to its European counterparts. ${ }^{5}$ The midnineteenth century Ottoman state effort to acquire information on economic and demographic structure was in fact a simultaneous development with European states, ${ }^{6}$ however, the relatively weak Ottoman central bureaucracy was simply overwhelmed with the data it gathered and could neither process them nor devise the planned tax reform. ${ }^{7}$ Subsequently, the deluge of this microdata found their way into a total of 20,000 registers, all of which were never tabulated, used or analysed by the Ottoman state nor by economic historians in a systematic manner until today. There have been good examples of creative uses with these registers for single urban locations, the most extensive of which has been on Thessaloniki. ${ }^{8}$ Thus far, the vast number of people and households documented in these Ottoman tax registers are too numerous to individually analyse, especially for the Ottoman rural economy. These handwritten registers 
contain a wealth of information, but its computerised text recognition is not a possibility for now. The manual reading of these tax registers require very high skills and ultimately is a time-consuming human intelligence task. For that reason, we must sample villages and archival sources to extract and analyse data based on agricultural production for a regional scale. Just to exemplify the sheer size of the scale of available albeit difficult to harvest data, we would like to underline that only in the Plovdiv region aforementioned Ottoman tax registers cover around 28,000 individual households in 400 villages. Our data sample for the Plovdiv region encompassed of approximately five percent of its total villages, five percent of its total population, and 4,000 individual entries only for grain production, all of which were manually entered.

The data on agricultural production from this survey includes a detailed mix of agricultural products (grains cultivated, fruits and vegetables grown), total area of cultivation, and total value of agricultural production. In the UrbanOccupationsOETR project, we have designed a relational database structure to manually enter economic information and production data in their entirety for chosen villages using a customized MS Access data entry template.

The first agricultural census of Bulgaria was conducted in 1897 and it provides minute detail on sown land and total production for various crops with high spatial resolution on three levels: i) obschina (communes or collection few villages), ii) okoliyas (sub-districts), and iii) okrags (districts). ${ }^{9}$ A total of 11 sub-categories of grains are given in the 1897 census which were published in Bulgarian and French. We translated them into English as follows: wheat, rye, maslin, barley, oats, emmer, corn, millet, rice, buckwheat, and total grains. For 1897, we have extracted wheat, barley, and total grain production figures and calculated their respective shares corresponding to okrag and okoliya level corresponding to our chosen regions of Plovdiv and Ruse (Table 1).

\section{GEO-SAMPLING MODEL}

Using our geo-sampling method, we aggregated the 1845 agricultural data on grain production extracted from Ottoman temettuat registers to commensurable units using sub-district level and compared it with grain production from the 1897 Bulgarian census for our chosen regions of Plovdiv and Ruse. The data allowed us to create shared and common units of analysis for 1845 and 1897 data using sub-districts (okoliyas in Bulgarian, and kazas or nahiyes in Ottoman). For the sake of clarification, we will hereafter refer to those territories, for which we will create polygons and corresponding attribute tables for our GIS analysis, as sub-units. We have created four sub-units per region for our 1845 data (Table 2, and Figure 2 for Plovdiv). We will use share of barley and wheat in total grain production as a proxy for the degree of export-oriented agricultural 
Table 1. Volumes and percentage shares of re-grouped grains production, 1897 Bulgarian agricultural census.

\begin{tabular}{|l|r|r|r|r|r|r|}
\hline $\begin{array}{l}\text { 1897 } \\
\text { Agricultural } \\
\text { Census }\end{array}$ & $\begin{array}{r}\text { wheat) } \\
\text { (tonnes) }\end{array}$ & $\begin{array}{c}\text { barley) } \\
\text { (tonnes) }\end{array}$ & $\begin{array}{l}\text { all } \\
\text { grains } \\
\text { (tonnes) }\end{array}$ & $\begin{array}{l}\text { \% of } \\
\text { wheat }\end{array}$ & $\begin{array}{l}\text { \% of } \\
\text { barley }\end{array}$ & $\begin{array}{l}\text { \% of } \\
\text { other } \\
\text { grains }\end{array}$ \\
\hline Plovdiv (okrag) & $\mathbf{3 6 , 5 5 8}$ & $\mathbf{8 , 8 6 4}$ & $\mathbf{1 0 4 , 4 4 6}$ & $\mathbf{3 5}$ & $\mathbf{8}$ & $\mathbf{5 7}$ \\
\hline Karlovo & 5,931 & 1,051 & 18,401 & 32 & 6 & 62 \\
\hline Konush & 4,301 & 2,226 & 22,334 & 19 & 10 & 71 \\
\hline Ovchi-Halm & 14,427 & 1,814 & 24,056 & 60 & 8 & 32 \\
\hline Plovdiv & 4,642 & 1,777 & 14,079 & 33 & 13 & 54 \\
\hline Rupchos & 359 & 168 & 5,201 & 7 & 3 & 90 \\
\hline Sarnena-Gora & 6,898 & 1,828 & 20,375 & 34 & 9 & 57 \\
\hline Ruse $(\boldsymbol{o k r a g})$ & $\mathbf{1 5 5 , 8 1 9}$ & $\mathbf{3 8 , 0 7 4}$ & $\mathbf{4 1 3 , 9 6 5}$ & $\mathbf{3 8}$ & $\mathbf{9}$ & $\mathbf{5 3}$ \\
\hline $\begin{array}{l}\text { Balbunar / } \\
\text { Kubrat }\end{array}$ & 19,192 & 3,733 & 35,353 & 54 & 11 & 35 \\
\hline Bela & 15,577 & 3,706 & 38,898 & 40 & 10 & 50 \\
\hline Kemanlar & 15,754 & 2,881 & 25,528 & 62 & 11 & 27 \\
\hline Nikopol & 19,316 & 3,142 & 65,171 & 30 & 5 & 66 \\
\hline Popovo & 17,788 & 2,857 & 41,882 & 42 & 7 & 51 \\
\hline Razgrad & 21,430 & 6,264 & 50,785 & 42 & 12 & 45 \\
\hline Ruse & 13,109 & 6,316 & 48,994 & 27 & 13 & 60 \\
\hline Svishtov & 15,487 & 5,015 & 61,350 & 25 & 8 & 67 \\
\hline Tutrakan & 18,165 & 4,160 & 46,003 & 39 & 9 & 51 \\
\hline $\begin{array}{l}\text { Pazardzhik } \\
\text { (okrag) }\end{array}$ & $\mathbf{1 1 , 9 6 0}$ & $\mathbf{4 , 3 1 9}$ & $\mathbf{5 0 , 5 2 0}$ & $\mathbf{2 4}$ & $\mathbf{9}$ & $\mathbf{6 8}$ \\
\hline Panagyurishte & 3,567 & 936 & 14,808 & 24 & 6 & 70 \\
\hline Pazardzhik & 7,100 & 2,837 & 28,189 & 25 & 10 & 65 \\
\hline Peshera & 1,293 & 546 & 7,522 & 17 & 7 & 76 \\
\hline Grand Total & $\mathbf{2 0 4 , 3 3 8}$ & $\mathbf{5 1 , 2 5 7}$ & $\mathbf{5 6 8 , 9 3 1}$ & $\mathbf{3 6}$ & $\mathbf{9}$ & $\mathbf{5 5}$ \\
\hline
\end{tabular}

production in our temporal comparison between the 1840s and the 1890 s for Plovdiv and Ruse.

As mentioned above, the 1845 tax register provides raw, unencoded, household level microdata on agricultural production. In our sample explained below and tabulated in Table 2, we have a total of 2,411 households, in 45 villages, in eight sub-units. There are 44 individual 1845 tax registers listed in the archival sources section at the end of this paper. Our team has manually entered the entire economic information conveyed in those registers into a MS Access database. The dataset we constructed lists a total of 11,998 tax items on agricultural production and on animal husbandry for our sample. 9,377 of these tax items are tithe records, which had been the backbone of Ottoman agricultural taxation. $.^{10} 5,900$ of those tithe entries are in grains categories (wheat, barley, rye, corn, oats), and 5,683 tithe entries for grains production provide us with 
Table 2. Volumes and percentage shares of re-grouped grains production, 1845 Ottoman tax registers for sub-units.

\begin{tabular}{|c|c|c|c|}
\hline Sub-unit & $\begin{array}{l}\text { Total } \\
\text { entries }\end{array}$ & $\begin{array}{l}\text { Total production } \\
\text { in kıyye }\end{array}$ & $\begin{array}{l}\text { \% shares of } \\
\text { categories in total } \\
\text { grains production }\end{array}$ \\
\hline Svishtov & 435 & 39,967 & \\
\hline Wheat & 176 & 18,636 & 47 \\
\hline Barley & 175 & 14,832 & 37 \\
\hline Other grains & 84 & 6,499 & 16 \\
\hline Sub-unit & $\begin{array}{l}\text { Total } \\
\text { entries }\end{array}$ & $\begin{array}{l}\text { Total production } \\
\text { in kile }\end{array}$ & $\begin{array}{l}\text { \% shares of } \\
\text { categories in total } \\
\text { grains production }\end{array}$ \\
\hline Asenovgrad & 1,010 & $8,713.5$ & \\
\hline Wheat & 284 & 4318 & 50 \\
\hline Barley & 213 & 1515 & 17 \\
\hline Other grains & 513 & $2,880.5$ & 33 \\
\hline Karlovo & 1,298 & $3,561.5$ & \\
\hline Wheat & 596 & $2,046.5$ & 57 \\
\hline Barley & 288 & 600 & 17 \\
\hline Other grains & 414 & 915 & 26 \\
\hline Pazardzhik & 1,199 & $3,293.5$ & \\
\hline Wheat & 377 & 1291.5 & 39 \\
\hline Barley & 237 & 530.5 & 16 \\
\hline Other grains & 585 & 1471.5 & 45 \\
\hline Plovdiv & 425 & $1,895.25$ & \\
\hline Wheat & 138 & 904.5 & 48 \\
\hline Barley & 119 & 484.5 & 26 \\
\hline Other grains & 168 & 506.25 & 27 \\
\hline Razgrad & 909 & $6,617.5$ & \\
\hline Wheat & 455 & 4,789 & 72 \\
\hline Barley & 432 & $1,791.5$ & 27 \\
\hline Other grains & 22 & 37 & 1 \\
\hline Ruse & 189 & 610.5 & \\
\hline Wheat & 101 & 330 & 54 \\
\hline Barley & 82 & 275.5 & 45 \\
\hline Other grains & 6 & 5 & 1 \\
\hline Tutrakan & 218 & 301 & \\
\hline Wheat & 117 & 184.5 & 61 \\
\hline Barley & 98 & 110 & 37 \\
\hline Other grains & 3 & 6.5 & 2 \\
\hline Grand Total & 5,248 & $24,992.75$ & \\
\hline Wheat & 2,068 & 13,864 & 55 \\
\hline Barley & 1,469 & 5,307 & 21 \\
\hline Other grains & 1,711 & $5,821.75$ & 23 \\
\hline
\end{tabular}




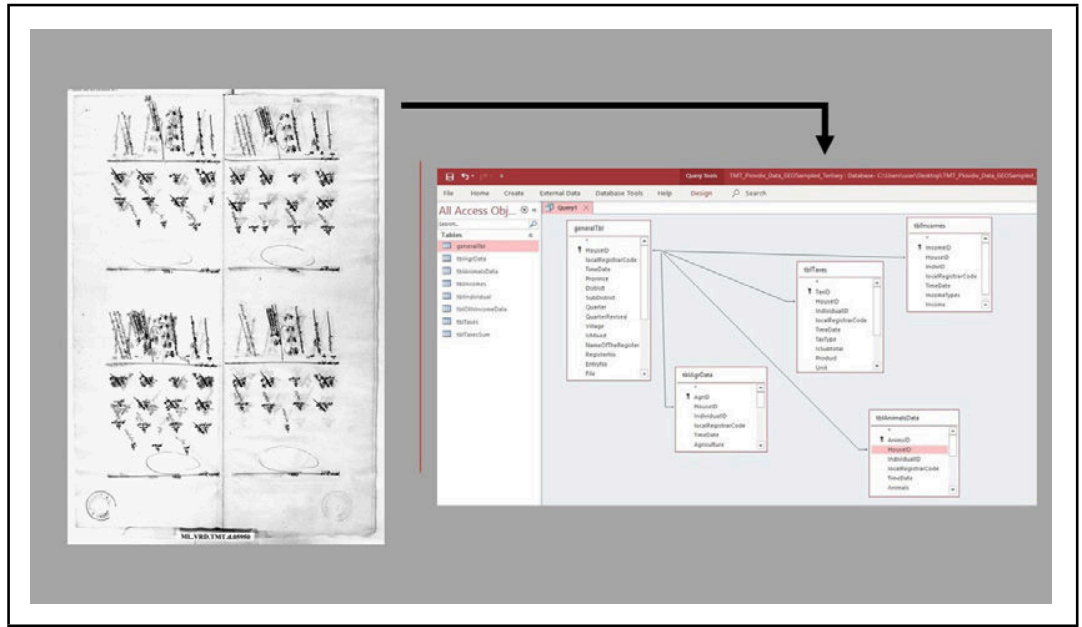

Figure 1. A sample page for Plovdiv rural tax register from 1845 covering four households, ML.VRD.TMT.d.5950, Ottoman state archives, Istanbul and the data structure in MS Access.

commensurable Ottoman units of weight measurement (5,248 in kile and 435 in klyye). In seven of our eight sub-units grains production are registered in kile or can be converted ${ }^{11}$ into kile. Only in Svishtov sub-unit grains production is registered in kıyye. Therefore, we do not need to convert these two units in order to calculate the percentage shares of wheat and barley in total grains production in our eight sub-units.

There are two primary reasons which led to the pursuit of developing a landuse suitability model and geo-sampling strategy for our research. The first reason came from the necessity to devise a particular sampling strategy to analyse the large amount of pre-census Ottoman population and tax registers and census data that we could gather from the two instances in the nineteenth century: the 1840s and 1897. We consider that the available information in the Ottoman population registers for 400 villages in the Plovdiv region and 294 in the Ruse region illustrates an excessive amount of available micro level historical, economic and demographic data for mid-nineteenth century Ottoman Empire. These 694 villages in those two regions encompass 45,933 households, which necessitate a sampling strategy to analyse on a macro scale and to take into consideration of regional historical agricultural dynamics. As mentioned earlier and shown in Figure 1, Ottoman tax registers contain very detailed information related to economic structure and their joint use in combination with the demographic data included in the Ottoman populations registers from the same period, opens up unprecedented opportunities for economic and social history as well as, material 
for novel application of geospatial history for several aspects. For the limited scope of this paper, and for the construction of this model, we focused on agricultural production. Nevertheless, we are convinced that the same model could be utilized for other aspects of rural economy in Southeast Europe and to bridge pre-census microdata with census data.

The purpose in our opting for a geo-sampling strategy instead of a random one, without taking into consideration certain geographical features such as physical endowments, was to include decisive elements relevant to agricultural production such as ruggedness, soil quality, and connectivity such as access to markets. While the assessment of land use suitability models is a common practice conducted in different fields, often used in planning and other deterministic purposes, selecting Ottoman archival data via geo-spatial methods has not been attempted before at the time of this writing.

The criteria we used were carefully selected after a review of the available literature and using an overall deductive approach. As Alberti et al. also consider, the construction of a Suitability Model is: 'a complex interplay between at least socio-cultural, economic, climatic, environmental, and topographic factors that may indeed affect the inherent properties of the land in the context of its use as well as of its abandonment'. ${ }^{12}$ Considering that our model should be as applicable to the most possible extent for diverse agricultural mixes, we did not limit our suitability model to a particular type of crop.

We devised our suitability model with three main components (Figure 2):

1- Soil quality: data for which can be downloaded for our two regions, Plovdiv, and Ruse, from ESDAC (European Soil Data Centre: https://esdac.jrc.ec.europa.eu/).

2- Ruggedness (suitability for cultivation): using available Shuttle Radar Topography Mission (SRTM) data with 30-meter spatial resolution, we have created our Digital Elevation Model to analyse agricultural suitability for our village-polygons based upon their relative positioning according to elevation, slope, and ruggedness.

3- Connectivity: We have map-mined reliable and detailed information on transport facilities from the Third Military Mapping Survey of AustriaHungary for a large territory in Southeast Europe and vectorised the road infrastructure. ${ }^{13}$ We assigned values of connectivity, moderately or highly accessible according to the relative distances to the closest roads suitable for wheeled vehicles (less than $500 \mathrm{~m}$ or not) and to the Danube, which is a major inland transport medium (less than $2 \mathrm{~km}$ or not).

In the next step, we defined and assigned territories with geographical boundaries for historical villages covered by mid-nineteenth century Ottoman registers. As there are no maps with historical village boundaries for this period, 


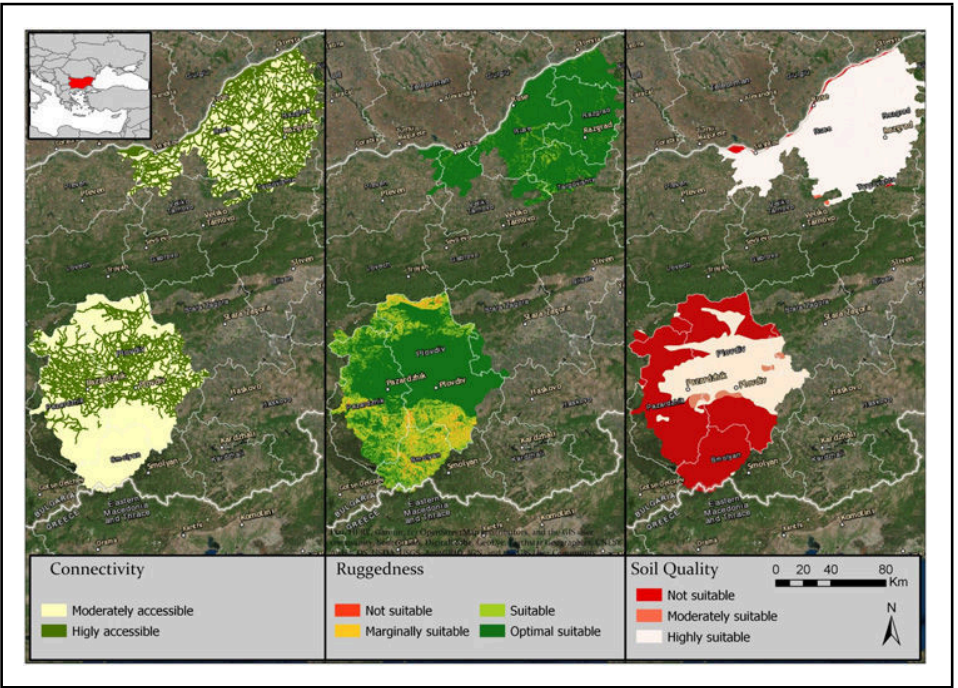

Figure 2. Multi-attribute criteria suitability raster.

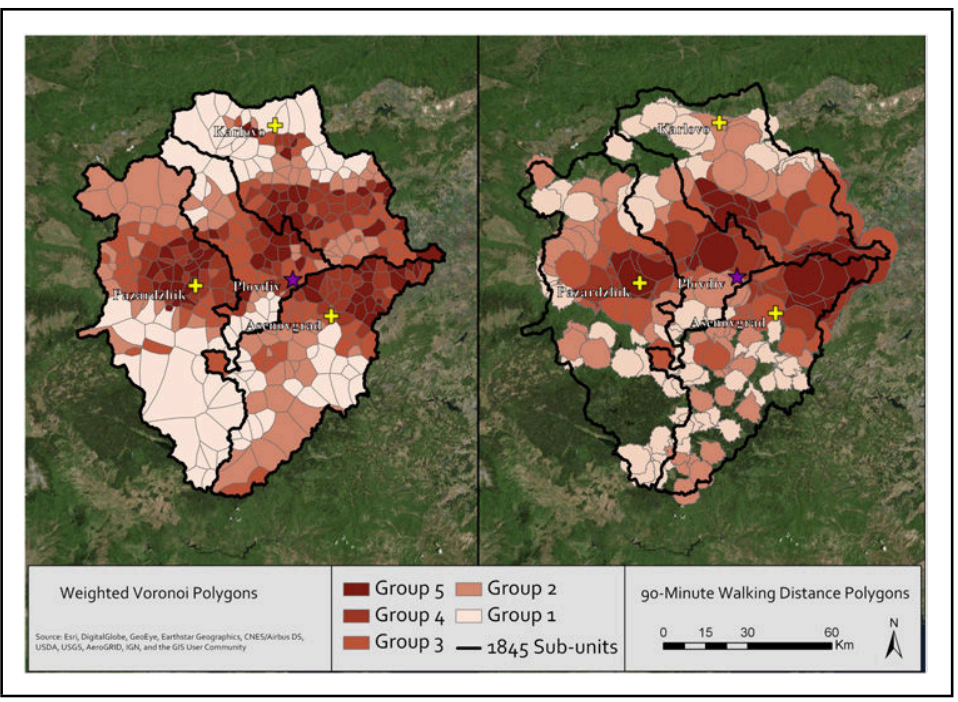

Figure 3. 1845 sub-units for Plovdiv region and village polygons (multiplicatively household number weighted Voronoi interpolation, versus Tobler hiking function 90-minute walking distance polygons on SRTM-DEM). 
in order to compare and to standardize historical quantitative data, we developed two methods to define geographical boundaries for villages.

The first model creates village boundaries based on the calculation of polygons, using multiplicatively weighted Voronoi interpolation. This interpolation technique, shown in Figure 3, does not only take into account the shared Euclidean distance between each input point (400 villages in Plovdiv region), like regular Voronoi or Thiessen interpolation, but also considers weighted input values. In our model, we used log values based on the total household size of each village to scale perimeters proportionally, using an ArcGIS add-on to calculate multiplicatively weighted Voronoi diagrams from input points. ${ }^{14}$

In the second model, we constrained territories assigned to villages to the maximum walking distance that villagers would have hypothetically walked to surrounding agricultural fields from village centres. Based on the observation of several georeferenced historical maps from the 1860s from our period of interest, ${ }^{15}$ designating village centres and surrounding agricultural fields, we found that on average fields were laid at a maximum of a 90-minute walking distance from village centres. We used this time distance to construct a model using ArcGIS Pro's built-in path distance tool and the Tobler Hiking function, a commonly used exponential function for the proximation of walking distance based on slope, to estimate village perimeters that would be walkable within a 90-minute range. ${ }^{16}$

After applying spatial boundaries in using the two methods explained above, it is possible to standardize the above listed suitability input features using a simple analytical hierarchy process (AHP). This AHP analysis was conducted within ArcMap 10.4, by making use of the extAHP 2.0 add-on, developed by Marinoni. ${ }^{17}$ We weighted soil quality with 50 per cent, suitability for cultivation with 35 per cent, and connectivity with 15 per cent in our model and created five groups/clusters of suitability. We based the lower role of the connectivity in the overall calculations, as the larger research area benefits an inductive approach as suggested by Overmars et al. ${ }^{18}$ However, since the latter method (Figure 3, right) created very similar suitability groupings compared to the former, it is more representative for actual terrain used in cultivation. Hence, in this paper we are operating with our 90-minute-walking-distance method to determine villagepolygons to group around 700 villages in two regions, Plovdiv and Ruse, into five categories of suitability (Figure 3, Table 3).

We sampled 20 villages for Plovdiv and 25 for Ruse region, which not only correspond to 5 per cent of villages in question but also around 5 per cent of total households in those sub-units. For four sub-units (Plovdiv, Ruse, Tutrakan, Svishtov) our 5 per cent sampling corresponds to less than five villages. For these sub-units we opted to round up to five randomly selected villages to be able to include one village from five different suitability groups. For the Razgrad 


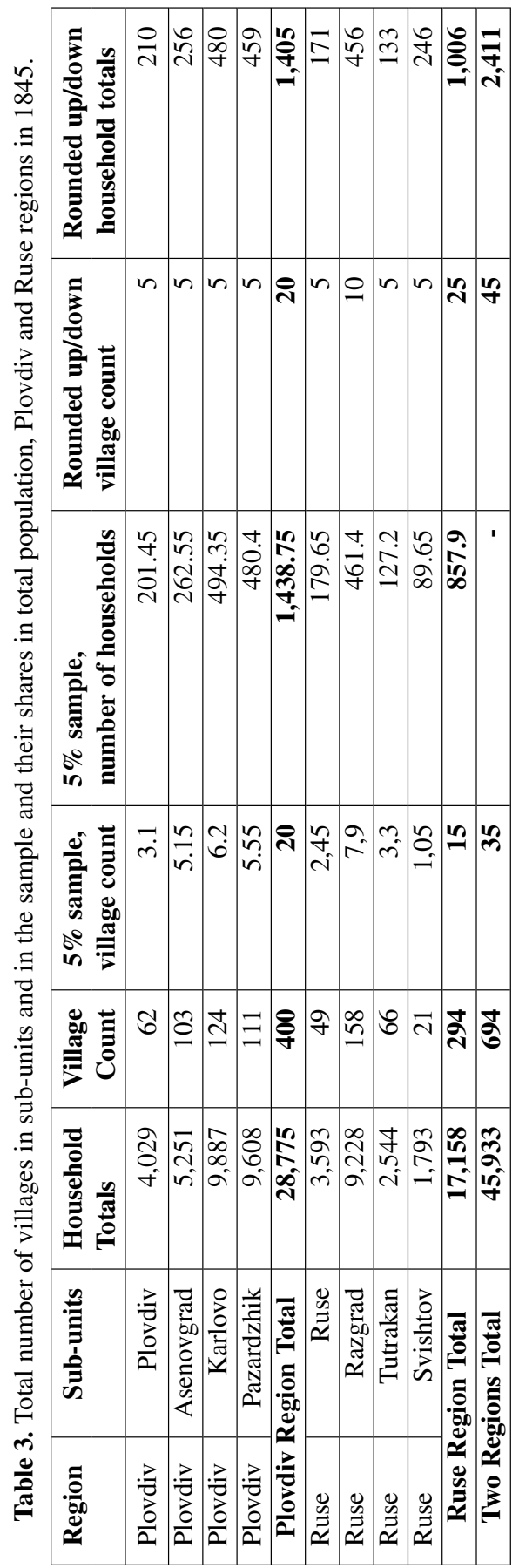


sub-district on the other hand, since 5 per cent of the villages were close to eight, we opted for ten randomly selected villages to represent two villages from each suitability group. For rest of the sub-units, we set five as number of sample villages since 5 per cent of villages amounted to numbers close to five. We conducted our sampling via a custom-made random-selection model in ArcGIS pro, based on a Python script which selected the villages by operating within our suitability constraints i.e. soil quality, ruggedness, connectivity.

After the completion of this data entry which totalled 2,411 households, we were able to generate estimates for agricultural product mix and volume of production for eight sub-units in the Plovdiv and Ruse regions, for which we have commensurable data from agricultural censuses for the same units; all of which have gone through minor changes in the late nineteenth century and could be mapped easily (Figure 5).

\section{DATA CALIBRATION AND POLYGON MODIFICATIONS}

As shown in Table 1, Table 2 and in Figure 3, sub-units for 1845 and 1897 are not identical. In order to reach similar and comparable areas for sub-units, a final calibration should be made to sustain commensurability between agricultural mixes of territories in our chosen regions between 1845 and 1897.

For the Plovdiv region, the 1897 census did not cover the entire Plovdiv region. Several villages in the Asenovgrad sub-unit were not counted due to political disobedience exhibited from communities in the Rhodopes. ${ }^{19}$ Due to this lack of data, we cannot include Asenovgrad subunit into the temporal comparison. The other three sub-units in the Plovdiv region: Karlovo, Pazardzhik, and Plovdiv proper in 1845 as polygons could be matched to a large extent with merged polygons using sub-units of the 1897 census territories, which we named: 1897_Karlovo_Merged, 1897_Pazardzhik_Merged, 1897_Plovdiv_Merged.

For the Ruse region, the Svishtov sub-unit polygons in 1845 and 1897 do not differ substantially. Therefore, they can be used without further modification. For the Razgrad sub-unit on the other hand, we should create a modified polygon using sub-units from 1897 coming close to 1845 sub-unit. For Ruse and Tutrakan both 1845 and 1897 sub-unit polygons should be merged together to reach a comparable territory and corresponding modified polygons. We have re-adjusted total amounts and shares of wheat, barley, and other grain production accordingly to necessary merges (Table 4, Figure 5). In the last column of Table 4, we have calculated the differences in square kilometres as percentages for sub-unit polygons between two periods. The largest variation is 26 per cent in surface area for Svishtov sub-unit and around 20 per cent for other six subunits. To our understanding, these areal variations do not disqualify the modified 


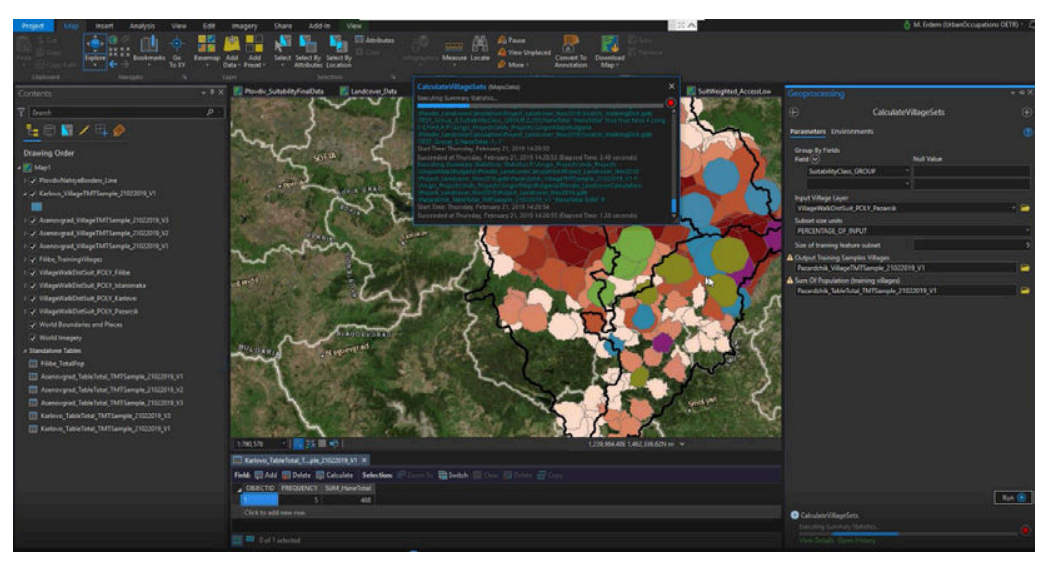

Figure 4. Geo-sample python script random generator, Plovdiv region.

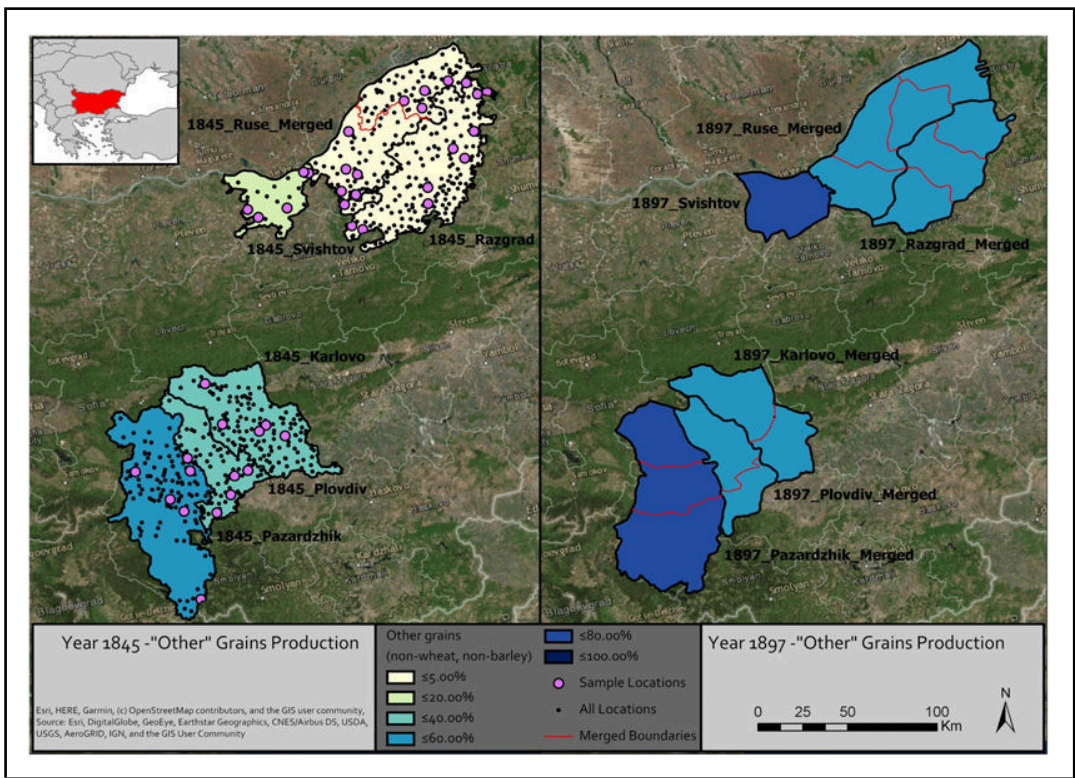

Figure 5. Visualization of drastic increase in share of other grains (non-wheat, nonbarley) for Plovdiv and Ruse regions between 1845 and 1897 . 
Table 4. Percentage share of wheat, barley, and other grains in modified sub-units in Plovdiv and Ruse in 1845 and 1897.

\begin{tabular}{|c|c|c|c|c|c|c|}
\hline Region & $\begin{array}{l}\text { Names of Modified } \\
\text { Sub-units }\end{array}$ & $\begin{array}{l}\text { \% wheat } \\
\mathrm{kg}\end{array}$ & $\begin{array}{l}\text { \% barley } \\
\mathrm{kg}\end{array}$ & $\begin{array}{l}\% \text { other } \\
\text { grains kg }\end{array}$ & $\begin{array}{l}\text { Area } \\
\text { sq. km }\end{array}$ & $\begin{array}{l}\% \text { Area } \\
\text { in } 1897 \\
\end{array}$ \\
\hline Plovdiv & 1845_Karlovo & 57 & 17 & 26 & 2,881 & 123 \\
\hline Plovdiv & 1845_Pazardzhik & 39 & 16 & 45 & 4,024 & 90 \\
\hline Plovdiv & 1845_Plovdiv & 48 & 26 & 27 & 1,616 & 90 \\
\hline Ruse & 1845_Razgrad & 72 & 27 & 1 & 3,576 & 122 \\
\hline Ruse & 1845_Ruse_Merged & 58 & 41 & 2 & 3,452 & 86 \\
\hline Ruse & 1845_Svishtov & 47 & 37 & 16 & 1,123 & 79 \\
\hline Region & $\begin{array}{l}\text { Names of } \\
\text { Modified Sub-units }\end{array}$ & $\begin{array}{r}\% \text { wheat } \\
\text { kg }\end{array}$ & $\begin{array}{r}\% \text { barley } \\
\text { kg }\end{array}$ & $\begin{array}{r}\% \text { other } \\
\text { grains kg }\end{array}$ & $\begin{array}{r}\text { Area } \\
\text { sq. } \mathbf{k m}\end{array}$ & $\begin{array}{l}\text { \% Area } \\
\text { in } 1845\end{array}$ \\
\hline Plovdiv & 1897_Karlovo_Merged & 33 & 7 & 60 & 2,340 & 81 \\
\hline Plovdiv & 1897_Pazardzhik_Merged & 22 & 8 & 70 & 4,470 & 111 \\
\hline Plovdiv & 1897_Plovdiv_Merged & 46 & 10 & 43 & 1,795 & 111 \\
\hline Ruse & 1897_Razgrad_Merged & 49 & 10 & 41 & 2,936 & 82 \\
\hline Ruse & 1897_Ruse_Merged & 40 & 11 & 49 & 4,009 & 116 \\
\hline Ruse & 1897_Svishtov & 25 & 8 & 67 & 1,417 & 126 \\
\hline
\end{tabular}

polygons for comparison. Instead of using areal interpolation techniques we opted for a geo-spatial regional interpretive use of these polygons to compare historical changes in agricultural mix with a focus on reliance or lack of dominance of wheat and barley in grain production.

\section{RESULTS AND CONCLUSIONS}

We argue that Figure 5 demonstrates a drastic fall of wheat and barley shares in grain production in both of our regions between 1845 and 1897 . We should clarify that although we operated percentages for our numerical and geo-spatial analysis, we are not after a quantitative measurement for the magnitude of changes in agricultural mixes in regions of Plovdiv and Ruse. We do not claim our approach with the geo-sampling method at the heart of it, has the methodological sophistication to quantify economic or agricultural change. Our analysis is designed to provide us with numerical indicators to analyse geospatial proxies for historical change. We are also aware of data limitations. Such as the fact that our 1845 data are coming from a tax-survey conducted by a weakened central empire in Bulgaria at a period when it was approaching its end in Southeast Europe. It should also be noted that the 1897 data was extracted from an agricultural census that was conducted by a new nation state albeit with higher statistical and bureaucratic capabilities. This is the reason, why we refrained from measuring differences in volumes of agricultural production. Our goal has been to geo-spatially analyse the changes in agricultural mix of 
grain production. Heavy dominance of wheat and barley are good indicators for an export-oriented grain production. If we make inter-regional comparisons for 1845 on reliance on wheat and barley, between Plovdiv and Ruse, it is evident that Ruse was a centre of wheat and barley production to a massive extent with a very high ratio of crop specialization. These findings are in accordance with historical accounts of Bulgarian lands providing massive amounts of grain to Istanbul via its Danube conduit. The same regional comparison in 1897 shows us that Ruse was no longer very different from the Plovdiv region regarding its lack of specialization of wheat and barley production within grains.

The sampling method suggested here, allows us to make a geo-spatially rooted regional temporal comparison of Bulgarian lands, before and after the independence from the Ottoman Empire, which is a novelty in Southeast European studies. The result of this comparison is that grain production of both regions lost their export-orientation status between 1845 and 1897, yet Ruse's agricultural production went through a more drastic change.

We are convinced that via bridging pre-census micro level data with census data using geo-sampling methods there are further opportunities to be explored in spatial humanities for long-term analyses.

\section{ARCHIVAL SOURCES}

Presidency of the Republic of Turkey, State Archives Department of Ottoman Archives (BOA)

Maliye Nezareti, Varidat Muhasebesi, Temettuat Kalemi Defterleri (ML.VRD.TMT.d.): 5950, 5952, 5955, 5956, 5958, 5960, 5964, 5967, 5968, 6076, 6244, 6260, 6310, 6368, 6394, 11949, 11954, 11958, 11986, 11997, 12019, 12042, 12047, 12072, 12076, 15959, 15961, 15965, 15967, 16388, 16514, 16542, 16597, 16682, 16694, 16801, 17108, 17317, 17472, 17800.

Kamil Kepeci (KK): 6073, 6074, 6075.

Haritalar (HRT.h.): 561, 562, 564, 565, 566, 567.

\section{ACKNOWLEDGMENTS}

This article is a joint research outcome of the project UrbanOccupationsOETR (urbanoccupations.ku.edu.tr), Industrialisation and Urban Growth from the mid-nineteenth century Ottoman Empire to Contemporary Turkey in a Comparative Perspective, 1850-2000, funded by the European Research Council (ERC) under the European Union's Horizon 2020 research and innovation programme (grant agreement No. 679097) conducted at Koç University, Istanbul. We would like to thank to other team members Efe Erünal, Mustafa Emre Günayd,, Osman Özkan, Semih Çelik, Sinan Kaya, Turgay Koçak for their careful reading of Ottoman archival sources and data entry and also to another team member, Avni Kyle Degirmenci for his language editing. 


\section{APPENDIX}

Appendix: Geo-sampled villages, sampled groups, household numbers, suitability index values, and surfaces of 90-minutes walking distances.

\begin{tabular}{|c|c|c|c|c|c|c|}
\hline Region & $\begin{array}{l}\text { Regional } \\
\text { Sub-unit }\end{array}$ & $\begin{array}{l}\text { Village } \\
\text { Modern } \\
\text { Name }\end{array}$ & $\begin{array}{l}\text { Suitability } \\
\text { Class }\end{array}$ & $\begin{array}{r}\text { Household } \\
\text { Total }\end{array}$ & $\begin{array}{r}\text { Suitability } \\
\text { Index }\end{array}$ & $\begin{array}{r}\text { Shape } \\
\text { Area } \\
(\mathbf{s q} . \mathbf{k m})\end{array}$ \\
\hline Ruse & Tutrakan & vanished & Group 1 & 18 & 0,00816 & 1445,23 \\
\hline Ruse & Tutrakan & Dryanovo-Kubrat & Group 2 & 31 & 0,00823 & 1508,92 \\
\hline Ruse & Tutrakan & vanished & Group 3 & 12 & 0,00831 & 1460,18 \\
\hline Ruse & Tutrakan & vanished & Group 4 & 37 & 0,00834 & 1495,88 \\
\hline Ruse & Tutrakan & Seslav & Group 5 & 35 & 0,00843 & 1491,74 \\
\hline Ruse & Razgrad & Gorski Senovets & Group 1 & 78 & 0,00820 & 1409,33 \\
\hline Ruse & Razgrad & Baniska & Group 1 & 76 & 0,00791 & 1207,26 \\
\hline Ruse & Razgrad & Elenovo & Group 2 & 51 & 0,00834 & 1414,69 \\
\hline Ruse & Razgrad & Paisiy & Group 2 & 43 & 0,00825 & 1426,28 \\
\hline Ruse & Razgrad & Golyamo novo & Group 3 & 62 & 0,00835 & 1334,48 \\
\hline Ruse & Razgrad & Yasenovets & Group 3 & 23 & 0,00841 & 1509,14 \\
\hline Ruse & Razgrad & Zhelyazkovets & Group 4 & 58 & 0,00843 & 1344,52 \\
\hline Ruse & Razgrad & Boil-joined & Group 4 & 20 & 0,00844 & 1495,00 \\
\hline Ruse & Razgrad & Bardokva & Group 5 & 20 & 0,00847 & 1510,71 \\
\hline Ruse & Razgrad & Zebil & Group 5 & 25 & 0,00847 & 1553,09 \\
\hline Ruse & Ruse & Basarbovo & Group 1 & 30 & 0,00794 & 1184,26 \\
\hline Ruse & Ruse & Bistrentsi & Group 2 & 49 & 0,00804 & 1412,79 \\
\hline Ruse & Ruse & Borovo & Group 3 & 19 & 0,00805 & 1420,44 \\
\hline Ruse & Ruse & Shirokovo & Group 4 & 40 & 0,00820 & 1185,68 \\
\hline Ruse & Ruse & Dve mogili & Group 5 & 33 & 0,00827 & 1468,32 \\
\hline Ruse & Svishtov & Belyanovo & Group 1 & 23 & 0,00823 & 1226,62 \\
\hline Ruse & Svishtov & Alekovo & Group 2 & 49 & 0,00825 & 1460,53 \\
\hline Ruse & Svishtov & Krivina & Group 3 & 59 & 0,00826 & 1043,41 \\
\hline Ruse & Svishtov & Morava & Group 4 & 53 & 0,00839 & 1487,38 \\
\hline Ruse & Svishtov & Stezherovo & Group 5 & 62 & 0,00844 & 1492,52 \\
\hline Plovdiv & Asenovgrad & Breze & Group 1 & 29 & 0,00306 & 443,98 \\
\hline Plovdiv & Asenovgrad & Boykovo & Group 2 & 33 & 0,00345 & 619,89 \\
\hline Plovdiv & Asenovgrad & Brestnik & Group 3 & 39 & 0,00620 & 1278,45 \\
\hline Plovdiv & Asenovgrad & Cherven & Group 4 & 87 & 0,00689 & 1207,53 \\
\hline Plovdiv & Asenovgrad & Konush & Group 5 & 68 & 0,00847 & 1564,02 \\
\hline Plovdiv & Pazardzhik & Chala & Group 1 & 74 & 0,00351 & 734,82 \\
\hline Plovdiv & Pazardzhik & Slavovitsa & Group 2 & 147 & 0,00502 & 1269,54 \\
\hline Plovdiv & Pazardzhik & Radilovo & Group 3 & 107 & 0,00586 & 1229,40 \\
\hline
\end{tabular}




\begin{tabular}{|l|l|l|l|r|r|r|}
\hline Region & $\begin{array}{l}\text { Regional } \\
\text { Sub-unit }\end{array}$ & $\begin{array}{l}\text { Village } \\
\text { Modern } \\
\text { Name }\end{array}$ & $\begin{array}{l}\text { Suitability } \\
\text { Class }\end{array}$ & $\begin{array}{r}\text { Household } \\
\text { Total }\end{array}$ & $\begin{array}{r}\text { Suitability } \\
\text { Index }\end{array}$ & $\begin{array}{r}\text { Shape } \\
\text { Area } \\
\text { (sq. km) }\end{array}$ \\
\hline Plovdiv & Pazardzhik & Lyahovo & Group 4 & 10 & 0,00789 & 1434,39 \\
\hline Plovdiv & Pazardzhik & Chernogorovo & Group 5 & 121 & 0,00835 & 1585,72 \\
\hline Plovdiv & Karlovo & Stoletovo & Group 1 & 69 & 0,00549 & 1119,99 \\
\hline Plovdiv & Karlovo & vanished & Group 2 & 24 & 0,00729 & 1507,87 \\
\hline Plovdiv & Karlovo & Varben & Group 3 & 30 & 0,00732 & 1406,67 \\
\hline Plovdiv & Karlovo & Streltsi & Group 4 & 73 & 0,00829 & 1558,85 \\
\hline Plovdiv & Karlovo & Brezovo & Group 5 & 284 & 0,00847 & 1558,71 \\
\hline Plovdiv & Plovdiv & Ustina & Group 1 & 121 & 0,00540 & 9463,25 \\
\hline Plovdiv & Plovdiv & Zlatitrap & Group 2 & 3 & 0,00700 & 1479,43 \\
\hline Plovdiv & Plovdiv & Ovchepoltsi & Group 3 & 64 & 0,00800 & 1560,58 \\
\hline Plovdiv & Plovdiv & Zhelyazno & Group 4 & 5 & 0,00838 & 1609,88 \\
\hline Plovdiv & Plovdiv & Tsaratsovo & Group 5 & 17 & 0,00851 & 1608,41 \\
\hline
\end{tabular}

\section{END NOTES}

${ }^{1}$ Z. Natan, ed., Ikonomika na Bŭlgariya [Economics of Bulgaria] (Sofia, 1969); I. Bozhilov et al., Istoriya na Bŭlgariya [History of Bulgaria] (Sofia, 1998).

2 M. R. Palairet, The Balkan economies c. 1800-1914: evolution without development (Cambridge, 1997).

3 A. Lyberatos, 'From imperial to national lands: Bulgarian agriculture from the RussianOttoman (1877-78) to the Balkan Wars (1912-1913)' in E. Eldem and S. Petmezas eds., The economic development of Southeastern Europe in the 19th century (Athens, 2011), 137-72.

${ }^{4}$ G. Demeter, Agrarian transformations in Southeastern Europe (from the late $18^{\text {th }}$ century to World War II) (Sofia, 2017). Cited here 160-67.

${ }^{5} \mathrm{~K}$. Hayashi and M. Aydin, eds., The Ottoman state and societies in change: a study of the nineteenth century temettuat registers, (London, 2004).

${ }^{6}$ A. Desrosières, The politics of large numbers: a history of statistical reasoning (Cambridge, Mass., 1998).

7 A. Efe, '1845 temettuat sayım sonuçları ne oldu' [What happened to the 1845 temettuat registers' results], History Studies, 8, 1 (2016), 19-35.

${ }^{8}$ D. Akyalçın Kaya, 'Les Sabbatéens saloniciens (1845-1912): des individus pluriels dans une société urbaine en transition' (unpublished Ph.D. thesis, École des Hautes Études en Sciences Sociales, 2013).

9 Direction de la statistique, Les résultats des ensemencements et la récolte dans la Principauté Bulgarie pendant l'année agricole, 1897-1898 (Sofia, 1900).

${ }^{10}$ N. Özbek, 'Tax farming in the nineteenth-century Ottoman Empire: institutional backwardness or the emergence of modern public finance?', The Journal of Interdisciplinary History 49, 2 (2018), 219-45.

11 Ü. Taşkın, 'Osmanlı devleti'nde kullanılan ölçü ve tartı birimleri’ [Measure and weight units used in the Ottoman Empire]" (unpublished MA thesis, Firat University, 2005). 
12 G. Alberti, R. Grima, and N. C. Vella, 'The use of geographic information system and 1860s cadastral data to model agricultural suitability before heavy mechanization. A case study from Malta', in H. Rebelo, ed., PLoS ONE 13, 2 (2018).

13 J.-L. Arnaud, 'The long life of a 1:200,000 map of Central Europe and the Balkans', in E. Liebenberg, P. Collier, and Z. G. Török, eds., History of cartography: international symposium of the ICA, 2012, lecture notes in geoinformation and cartography (Berlin, 2014), 111-28.

14 P. Dong, 'Generating and updating multiplicatively weighted Voronoi diagrams for point, line and polygon features in GIS', Computers \& Geosciences 34, 4 (2008), 411-21.

15 BOA, Haritalar (HRT.h.): 561, 562, 564, 565, 566, 567.

${ }^{16}$ W. R. Tobler, 'A computer movie simulating urban growth in the Detroit region', Economic Geography 46 (1970), 234-40.

17 O. Marinoni, 'Implementation of the analytical hierarchy process with VBA in ArcGIS', Computers \& Geosciences 30, 6 (2004), 637-46.

18 K. P. Overmars, P. H. Verburg, and T. A. Veldkamp, 'Comparison of a deductive and an inductive approach to specify land suitability in a spatially explicit land use model', Land Use Policy 24, 3 (2007), 584-99.

19 M. N. Todorova, Scaling the Balkans: essays in national, transnational and conceptual history (Leiden, 2018). Cited here at 391. 